\title{
EKONOMI KREATIF SEBAGAI PELUANG REMAJA AUTISTIK BERWIRAUSAHA
}

\author{
Chrisdina, Jefri Audi Wempi, Nurul Hidayah. \\ Institut Komunikasi dan Bisnis LSPR \\ chrisdina@1spr.edu, wempi@1spr.edu, nurul.h@1spr.edu
}

\begin{abstract}
The existence of autistic individuals in Indonesia continues to increase, this can be seen from the number of inclusive schools that continue to emerge. The increase in the number of schools provides wider opportunities to have abilities both academically and skills. The academic ability achieved has not been able to allow autistic adolescents to have a job. Apart from that, parents also need to get an understanding of how to make an effort that these autistic adolescents can do. The creative economy, especially crafts, can be a solution to these problems. The LSPR Communication and Business Institute sees this phenomenon as an opportunity to be able to develop an empowerment program for autistic adolescents so that they can have the opportunity to be able to earn their own income. Through the work training center program, autistic adolescents are taught the skills to process textiles using dyeing techniques. During the Covid 19 pandemic the learning system applied was online. The advantage of online training allows parents to assist and be able to ask questions from the process to the opportunity to market the product. After the program has been running for 6 months, 2 home businesses have been formed, which have been carried out by autistic teenagers and their parents. It was concluded that the empowerment program for adolescents with autism must be accompanied by building awareness and the communication is well accepted. ability of parents to become entrepreneurs. The use of google meet as a new technology in
\end{abstract}

Keywords: autism youth; creative economy; entrepreneurship

\begin{abstract}
Abstrak
Keberadaan individu autis di Indonesia terus bertambah, ini nampak dari jumlah sekolah inklusi yang terus bermunculan. Pertambahan jumlah sekolah memberikan peluang yang lebih luas untuk memiliki kemampuan baik secara akademik maupun keterampilan. Kemampuan akademik yang dicapai belum dapat memberikan kesempatan para remaja autis memiliki pekerjaan. Selain hal itu orangtua juga perlu mendapat pemahaman bagaimana membuat sebuah usaha yang mampu dilakukan oleh para remaja autis tersebut. Ekonomi kreatif khususnya kerjainan dapat menjadi salah satu pemecahan masalah tersebut. Institut Komunikasi dan Bisnis LSPR melihat fenomena tersebut menjadi sebuah peluang untuk dapat mengembangkan sebuah program pemberdayaa remaja autis agar mampu memiliki peluang untuk dapat memiliki penghasilan sendiri. Melalui program balai latihan kerja para remaja autis diajari keterampilan mengolah teksil dengan teknik celup. Pada masa pandemi Covid 19 sistem pembelajaran yang diterapkan adalah melalui daring. Keuntungan pelatihan daring memberikan kesempatan orangtua untuk mendampingi dan dapat bertanya mulai dari proses hingga kesempatan untuk memasarkan produk. Setelah program berjalan 6 bulan sudah terbentuk 2 usaha rumahan yang dikerjakan oleh remaja autis dan orangtuanya. Disimpulkan bahwa program pemberdayaan reamja autis harus dibarengi dengan dibangunnya kesadaran dan kemampuan orangtua untuk berwirausaha. Penggunaan media google meet sebagai teknologi baru dalam berkomunikasi dapat diterima dengan baik.
\end{abstract}

Kata kunci: remaja autis, ekonomi kreatif, wirausaha 


\section{PENDAHULUAN}

Pertumbuhan angka individu autis di Indonesia terus melaju naik, hal ini dapat terlihat dari semakin banyaknya sekolah inklusi yang bermunculan. Selain hal tersebut pemerintah melalui peraturan Kementerian Pendidikan dan
Kebudayaan juga mendukung dengan mengeluarkan peraturan bagi setiap sekolah negeri untuk menerima 1 siswa berkebutuhan khusus dalam setiap kelas. Pertambahan jumlah sekolah swasta inklusi yang mencapai 1.457 sekolah.

Tabel 1. Jumlah Sekolah Swasta Inklusi di beberapa Provinsi

\begin{tabular}{llc}
\hline NO & \multicolumn{1}{c}{ PROVINSI } & TOTAL \\
\hline $\mathbf{1}$ & Provinsi Jawa Timur & 378 \\
\hline $\mathbf{2}$ & Provinsi Jawa Barat & 345 \\
\hline $\mathbf{3}$ & Provinsi Jawa Tengah & 154 \\
\hline $\mathbf{4}$ & Provinsi Sumatera Barat & 127 \\
\hline $\mathbf{5}$ & Provinsi Banten & 99 \\
\hline $\mathbf{6}$ & Provinsi D.K.I. Jakarta & 85 \\
\hline $\mathbf{7}$ & Provinsi D.I. Yogyakarta & 77 \\
\hline $\mathbf{8}$ & Provinsi Sulawesi Selatan & 69 \\
\hline $\mathbf{9}$ & Provinsi Sulawesi Tenggara & 69 \\
\hline $\mathbf{1 0}$ & Provinsi Aceh & 54 \\
\hline
\end{tabular}

Sumber : www.referensi.data.kemdikbud.go.id(2020)

Pada data dapat terlihat bahwa jumlah sekolah swasta inklusi terbesar adalah di Provinsi Jawa Timur. Pertambahan lembaga pendidikan tentunya membuka kesempatan lebar bagi para individu autis untuk memiliki pendidikan yang mencapai tingkat tertinggi berdasarkan kemampuan yang mereka miliki. Melalui pendidikan tersebut diharapkan dapat membangun kemampuan akademik dan keterampilan menjadi lebih baik. Seperti disampaikan oleh ibu Tjut Sandy Ela Novamia (Liputan6.com, 2017) yang menaruh harapan kepada Pemerintah Indonesia ramah pada anak berkebutuhan khusus termasuk autis, Indonesia dapat meniru negara lain seperti negara Malaysia yang menjadi acuan negara-negara ASEAN untuk ilmu pengetahuan anak-anak berkebutuhan khusus. 
Sebagai orangtua dengan anak autis tentunya kemandirian baik dalam bersosialisasi maupun finansial menjadi masalah yang masih belum dapat terpecahkan dengan mudah. Keberadaan lembaga pendidikan inklusi hingga tingkat sekolah menengah atas masih belum dapat memberikan jawaban atas permasalahan tersebut. Aswin dari Direktorat PMPK Kemendikbud (Kompas.com, 2020) mengatakan bahwa masih ada

ketidakcocokan dari materi pendidikan dalam sekolah untuk $\mathrm{ABK}$ dengan kebutuhan di dunia kerja, Kemendikbud akan selalu memperbaiki dan mengembangkan kurikulum tersebut agar dapat sejalan dengan dunia kerja.

Harapan remaja autis untuk dapat bekerja pada sebuah perusahaan menjadi semakin jauh dan belum ada titik terang. Hal ini tampak pada jumlah individu autis yang telah memiliki pendidikan tetapi masih belum memiliki pekerjaan baik sebagai pegawai maupun berwirausaha. Menurut data dari Badan Pusat Statistik 2019 untuk angkatan kerja individu disabilitas menunjukan masih ada 289 ribu yang pengangguran (BPS, 2019).

Menurut Prahardika dkk (2015) Kaum disabilitas di Indonesia tidak hanya dapat bekerja sebagai karyawan di suatu perusahaan namun juga dapat membangun usaha sendiri seperti Usaha Kecil dan Menengah (UKM) yang tentunya dapat memberikan penghidupan yang layak bagi diri sendiri dan orang lain serta secara tidak langsung dapat mendukung kebijakan inkubasi pemerintah. Tidak sedikit dari para disabilitas memiliki keterampilan dalam berwirausaha dan kreatifitas di bidang lain yang dapat bernilai ekonomi. Melalui media sosial ditemukan ada beberapa usaha yang dilakukan oleh orang tua dengan anak autis. Di Indonesia pengguna media sosial yang aktif ada 160 juta dengan penggunaan media sosial yang paling banyak diakses yaitu Youtube, Whatsapp, Facebook, dan Instagram (Hootsuite, 2020). Menurut Nasrullah dalam Gumilar (2015) kehadiran media sosial dalam pemasaran era digital pemasaran era digital bisa dilihat dari dua sisi yakni sisi pengiklan dan sisi pengguna media sosial. Dari sisi pengiklan, media sosial memberikan tawaran dengan konten beragam. Iklan tidak hanya bisa diproduksi bentuk teks, tetapi juga audio, visual sampai audio visual. Produksi iklan dan pemanfaatan media sosial cenderung murah. Tidak hanya itu, target terhadap calon konsumen juga bisa ditentukan berdasarkan prosedur dari perangkat yang ada di media sosial (Gumilar, 2015).

Usaha yang dijalankan oleh orang tua dengan remaja autis nampak memberdayakan beragam hasil karya yang diolah sehingga memiliki nilai jual. Usaha ini tidak terlepas dari usaha orang tua yang berusaha untuk mengemas keterampilan yang dimiliki anaknya sehingga dapat dijadikan produk. Bukan hanya berkreasi dengan hasil karya saja, tetapi orang tua juga melakukan berbagai kegiatan promosi untuk memperkenalkan produk yang ingin dijual. Berikut ini adalah contoh dari usaha remaja autis yang siap dipasarkan. 


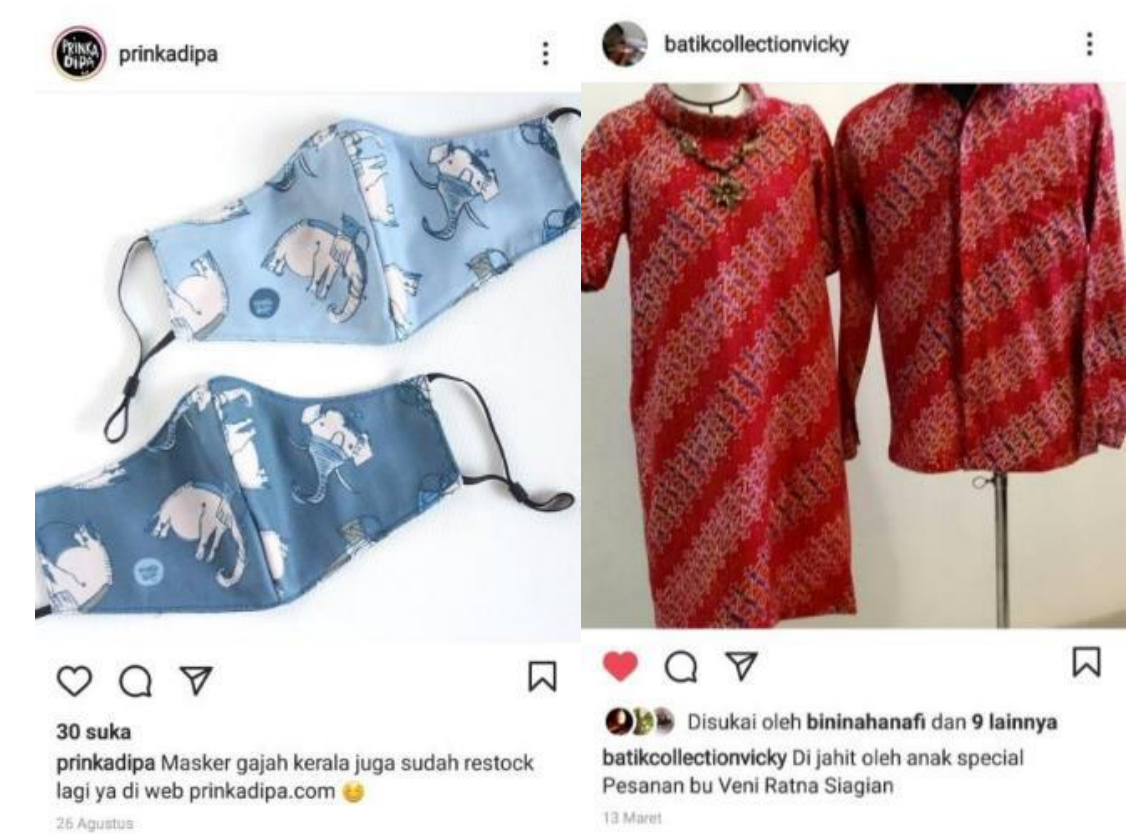

Gambar 1. Contoh Dari Usaha Remaja Autis Yang Siap Dipasarkan Sumber: instagram/prinkadipa , instagram/batikcollectionvicky

Usaha orang tua bersama remaja autis mendorong untuk melakukan wirausaha melalui media sosial ini mengikuti perkembangan zaman. Melakukan usaha melalui media sosial juga membantu mengembangkan ekonomi kreatif di Indonesia. Ekonomi kreatif menurut Purnomo (2016) adalah suatu konsep untuk merealisasikan pembangunan ekonomi yang berkelanjutan berbasis kreativitas. Pemanfaatan sumber daya yang bukan hanya terbarukan, bahkan tidak terbatas, yaitu ide, gagasan, bakat atau talenta dan kreativitas (Purnomo, 2016)

Berbeda dengan sektor-sektor lain yang sangat bergantung pada eksploitasi sumber daya alam, kekuatan ekonomi kreatif lebih didasarkan pada keunggulan sumber daya manusia. Masing-masing era ekonomi mengadopsi intelektualitas dan kreativitas seseorang sebagai aset utama, dan keberadaan industri kreatif yang menjadi perwujudan. Industri kreatif Indonesia ini menunjukan pertumbuhan yang kuat mulai dari 2010 hingga saat ini dengan konsisten mencatat pertumbuhan positif terhadap PDB negara, sehingga membuktikan ekonomi kreatif memiliki potensi besar untuk pertumbuhan (Lestari, 2020).

Menurut Zamzani, dkk (2018) ekonomi kreatif mempunyai 16 subsektor yaitu bidang aplikasi dan game developer, arsitektur, desain interior, desain komunikasi visual, desain produk, fashion, film, animasi, dan video, fotografi, kriya, kuliner, musik, penerbitan, periklanan, seni pertunjukan, seni rupa, televisi dan radio. Dari 16 subsektor berdasarkan hasil survei khusus tahun 2017 sektor unggulan adalah fashion sebesar 56\%, kriya sebesar $37 \%$, kuliner sebesar $6 \%$, dan yang lainnya rata-rata sekitar $1 \%$. 
Melihat kondisi tersebut sepintas terlihat bahwa para remaja autis ini masih memiliki harapan untuk memiliki kemandirian finansial dengan dukungan lingkungan yang tepat. Institut Komunikasi dan Bisnis LSPR (IKB LSPR) melihat permasalahan yang timbul sebagai sebuah peluang untuk dapat berkontribusi memberikan sebuah program pelatihan bagi remaja autis sehingga memiliki keterampilan yang dapat dipergunakan sebagai bekal masa depan. Sedangkan bagi orang tua diajak untuk memahami lebih dalam seluruh proses pembuatan produk agar dapat melihat kelebihan pada produkproduk yang dihasilkan. Melalui pelatihan dan pendampingan untuk remaja autis dan orang tua membuat wirausaha ini sangat berguna.

Pendampingan wirausaha untuk para individu berkebutuhan khusus membutuhkan banyak bantuan dari berbagai pihak. ini bagi remaja autis diperlukan pendampingan (Purwanta dkk, 2016). Menurut Haryanto (2010) pendidikan keterampilan kerja bagi warga berkebutuhan khusus pada intinya berorientasi pada upaya dapat bekerja, karena kerja merupakan aktivitas dasar dan dijadikan bagian yang esensi dari kehidupan manusia. Selain itu kerja dapat memberi kesenangan, serta makna tersendiri bagi kehidupan manusia, orang dapat hidup dan sekaligus merasa berguna, dibutuhkan dan dikehendaki masyarakat (Haryanto, 2010).

Pada pelatihan tersebut setiap remaja autis diajarkan untuk mampu bekerja dalam waktu yang telah ditentukan, kualitas yang memiliki nilai jual, dan kerapihan. Tambahan lain adalah mengajak mereka untuk memahami bagaimana berkomunikasi yang baik satu dengan lainnya. Sedangkan orang tua diberikan kesempatan untuk berdiskusi seputar produksi yang akan dijalankan. Selain itu orang tua juga diberikan contoh bagaimana mengemas produk hingga memiliki nilai jual serta melakukan promosi secara daring menggunakan media sosial.

\section{TINJAUAN LITERATUR}

Pada pelaksanaan program balai kerja terlihat bahwa proses yang terjadi dapat mengacu pada pola pembelajaran hal baru dengan dukungan teknologi. Pemikiran Rogers bahwa perkembangan inovasi terdiri dari keputusan, aktivitas, dan dampak yang terjadi akibat dari identifikasi kebutuhan atau masalah melalui penelitian, pengembangan, dan komersialisasi sebuah inovasi, melalui difusi dan adopsi inovasi tersebut oleh pengguna, juga konsekuensi yang muncul. (Rogers, 1983)

Menurut Rogers (1983) dalam pengambilan keputusan terdapat lima tahap yaitu:

1. Knowledge, pada tahap ini individu memperoleh informasi mengenai keberadaan inovasi baru dan memahami cara menggunakannya.

2. Persuasion, pada tahap ini individu membentuk sikap baik atau tidak baik terhadap inovasi.

3. Decision, pada tahap ini individu terlibat pada kegiatan yang mengarah pada pilihan untuk 
mengadopsi atau menolak inovasi.

4. Implementation, pada tahap ini individu memilih untuk mengadopsi inovasi yang ditawarkan, dengan mencoba menerapkan inovasi tersebut.

5. Confirmation, pada tahap ini individu (unit pengambilan keputusan lainnya) mencari penguatan atau pembenaran atas keputusan yang telah dibuat.

Pada esensinya difusi inovasi melihat bahwa ada proses mengajarkan sesuatu yang baru pada kelompok sosial tertentu. Kelompok sosial disini adalah bagaimana mengubah pola pikir orang tua yang meyakini bahwa anak-anak mereka tidak memiliki kesempatan untuk mandiri secara finansial. Menurut Rogers (1983) menjelaskan bahwa terdapat lima atribut inovasi yang mempengaruhi kecepatan difusi yaitu Keuntungan Relatif (Relative Advantage), Kesesuaian (Compatibility), Kerumitan (Complexity), Uji Coba (Triability), dan Pengamatan (Observability).

Pada keuntungan relatif (relative advantage) program balai latihan ini harus mampu memberikan keuntungan yang dirasakan langsung oleh para remaja dan orang tua. Ketika keuntungan tersebut dirasakan memberikan pengaruh pada perubahan maka sebuah inovasi akan mudah untuk diterima.

$$
\text { Menurut Rogers }
$$

keuntungan relatif (relative advantages) dapat dilihat dari sejauh mana sebuah inovasi dianggap sebagai ide yang lebih baik dari yang digantikannya. Tingkat keuntungan relatif ini sering dinyatakan dalam bentuk profitabilitas ekonomi, status sosial, dan lainnya. Kesesuaian(compatibility) program menjadi sebuah salah satu hal yang perlu diperhatikan agar tidak menimbulkan penolakan oleh lingkungan tertentu. Dalam hal ini lingkungan yang perlu diyakinkan adalah kelompok orang tua yang memiliki anak berkebutuhan khusus.

Kerumitan (complexity) merupakan elemen yang dipertimbangkan oleh sebuah lingkungan ketika menerima sebuah inovasi. Pada program balai latihan kerumitan yang dimaksud adalah cara konten pembelajaran yang diberikan serta teknik pengerjaannya. Menurut Rogers (1983) complexity adalah sejauh mana suatu inovasi dianggap relatif sulit untuk dipahami dan digunakan.

Pada tahapan dapat diuji coba (triability) program harus dapat memastikan bahwa peserta mampu melakukan praktek yang diajarkan tanpa pengawasan pengajar. Hal tersebut menjadi sebuah inovasi (innovation) yang dapat diakui oleh para orang tua. Menurut Rogers (1983) triability yaitu kemampuan suatu inovasi dapat diuji coba secara terbatas.

Menurut Rogers

pengamatan (observability) yaitu bagaimana hasil dari suatu inovasi dapat dilihat oleh orang lain. Pada program ini bagaimana hasil praktek peserta dapat diterima oleh masyarakat.

Rogers (1983) menyatakan bahwa saluran komunikasi dan jangka waktu juga harus dicermati. Program balai 
latihan menggunakan daring sebagai saluran komunikasi dengan jangka waktu tertentu. Demikian pula pada rangkaian keseluruhan program yang dilaksanakan selama 6 bulan.

\section{METODE PELAKSANAAN}

Karakteristik yang cukup unik yaitu remaja autism aka balai latihan berusaha untuk mencari metode yang paling tepat disaat pandemi. Pengajaran daring menjadi pilihan dan dianggap paling memungkinkan saat ini. Berbasis daring yang artinya proses pembelajaran tidak harus dilakukan dengan tatap muka secara langsung dengan penggunaan media platform sebagai penunjang dalam membantu proses belajar mengajar (Febriyanti dkk, 2020).

Sebagai persiapannya setiap anggota yang mengikuti program beserta orang tuanya diperkenalkan terlebih dahulu pada program belajar yang akan dipakai yaitu aplikasi google meet. Aplikasi yang digunakan harus mudah dipahami serta digunakan. Pada penggunaan aplikasi juga hanya dipilih fitur yang diperlukan saja sehingga peserta dan orang tua dapat fokus. Ini menjadi penting menyesuaikan karakteristik autis yang tidak dapat berkonsentrasi dalam jangka waktu panjang.

Metode lain yang diterapkan adalah memberikan video tutorial dalam durasi pendek. Melalui video peserta diperkenalkan dasar-dasar dari materi yang akan dipelajari sehingga para peserta dapat mengulang-ulang materi yang diberikan. Video pendek yang dibuat diunggah pada media sosial yang cukup dipahami serta dikenal oleh peserta dan orang tua, yaitu saluran youtube. Selain itu juga dilakukan proses evaluasi dengan meminta peserta untuk mengirimkan contoh hasil karya yang telah dibuat.

Tujuannya agar pengajar dapat memeriksa dan memberikan masukan kepada peserta agar karya yang dihasilkan menjadi lebih baik.

\section{HASIL DAN PEMBAHASAN}

Berawal dari pembuatan program balai latihan bagi individu autistik di tahun 2017 yang beranggotakan 5 peserta. Program yang berada di bawah kegiatan pengabdian masyarakat IKB LSPR ini melibatkan berbagai macam elemen, mulai dari dosen, karyawan, hingga mahasiswa. Tujuan pertama adalah memberikan bekal keterampilan khusushnya teknik celup kain kepada remaja autis yang telah lulus SMA. Kedua memberikan wawasan baru kepada orang tua agar mendukung anak untuk memiliki usaha sendiri, dan ketiga adalah memberikan harapan bagi remaja autis untuk mandiri dalam finansial. Setiap program dilaksanakan selama 6 bulan dengan maksimal peserta 20 orang. Program balai latihan juga menerima pemesanan produk sehingga peserta dapat benar-benar merasakan suasana bekerja dalam tenggat waktu yang ditentukan serta menerima honor.

Pada kelompok awal balai latihan masih belum menghasilkan lulusan yang berhasil menjalankan wirausaha. Hampir seluruh peserta kembali pada rutinitas hariannya seperti membantu orang tua atau mengikuti kursus-kursus 
keterampilan lainnya. Hal ini menjadi sebuah pekerjaan rumah yang harus dipecahkan oleh tim pengabdian masyarakat IKB LSPR. Pada kelompok kedua mulai diadakan pelatihan kewirusahaan sebagai tambahan yang ditujukan kepada orang tua peserta. Tujuan dari pelatihan tersebut adalah memberikan bekal pengetahuan bagaiman ketika orang tua akan memulai sebuah usaha bagi para putra-putrinya. Pelatihanyang diberikan juga belum mampu membangun kesadaran oragn tua untuk kreatif memncari solusi bagi masa depan putra putri mereka.

Memasuki pandemi Covid 19 menantang tim pengabdian masyarakat IKB LSPR untuk tidak berhenti menjalankan program balai latihan. Solusi yang diambil adalah mengubah cara pelatihan yang awalnya adalah tatap muka menjadi daring. Tentunya ini merupakan sebuah tantangan tersendiri mengingat karakteristik peserta yang sangat sulit untuk berkonsentrasi dalam waktu yang panjang. Proses pembelajaran daring juga belum pernah dilakukan oleh para peserta. Pada tahapan persiapan elemen dari tim pengabdian masyarakat memiliki tanggung jawab yang berbeda-beda, bagi dosen peran yang diberikan adalah membantu merancang program balai latihan melalui daring serta mempelajari cara belajar yang efektif. Pada pengajaran dilakukan oleh karyawan yang memiliki latar belakang ilmu pendidikan sehingga kegitan pelatihan dapat berjalan dnegan baik, sedangkan mahasiswa menjadi tenaga administrasi selama program berlangsung.
Pelaksanaan program balai latihan pada masa pandemi dibagi menjadi beberapa tahapan dimulai dari persiapan hingga pelaksanaan. Pada tahap persiapan tim mencari aplikasi belajar apa yang dianggap paling sesuai dengan mempertimbangkan karakteristik peserta. Ketika balai latihan dilakukukan dengan tatap muka maka setiap kelompok akan memiliki pendamping selain pengajar, tentunya hal ini tidak dapat dilakukan saat daring. Untuk itu tim memasukan orang tua sebagai pendamping, yang artinya harus diperhatikan juga karateristiknya. Setelah melakaukan berbagai macam percobaan pada aplikasi belajar maka diputusakan menggunakan google meet sebagai platform dengan pertimbangan mayoritas peserta dan orang tua memiliki akun email Gmail. Berikutnya adalah melengkapai modul pelatihan dengan video tutorial yang diberikan sebelum pelatihan dilakukan. Video yang dibuat tidak lebih dari 15 menit dengan alasan agar tidak menimbulkan kebosanan pada peserta. Setelah siap maka video diunggah pada channel youtube sehingga peserta dapat mengulang-ulang materi apabila diperlukan. Youtube juga bukan hal yang baru bagi peserta dan orang tua dan memudahkan untuk menggunakannya.

Kerajinan tangan adalah salah satu keterampilan yang mungkin diajarkan kepara remaja autis. Pembelajaran yang bersifat praktikal membantu memudahkan untuk menangkap setiap tahapannya. Tekni celup kain memiliki cara pengerjaan yang tidak terlalu sulit serta sangat minim tingkat kesalahannya. 
Bahan-bahan yang digunakan juga relatif aman bagi ramaja autis yang memiliki banyak alergi pada tubuhnya. Olahan kain yang dihasilkan pada balai latihan sangat beragam seperti kaos, kerudung, kain siap olah, dan sebagainya.

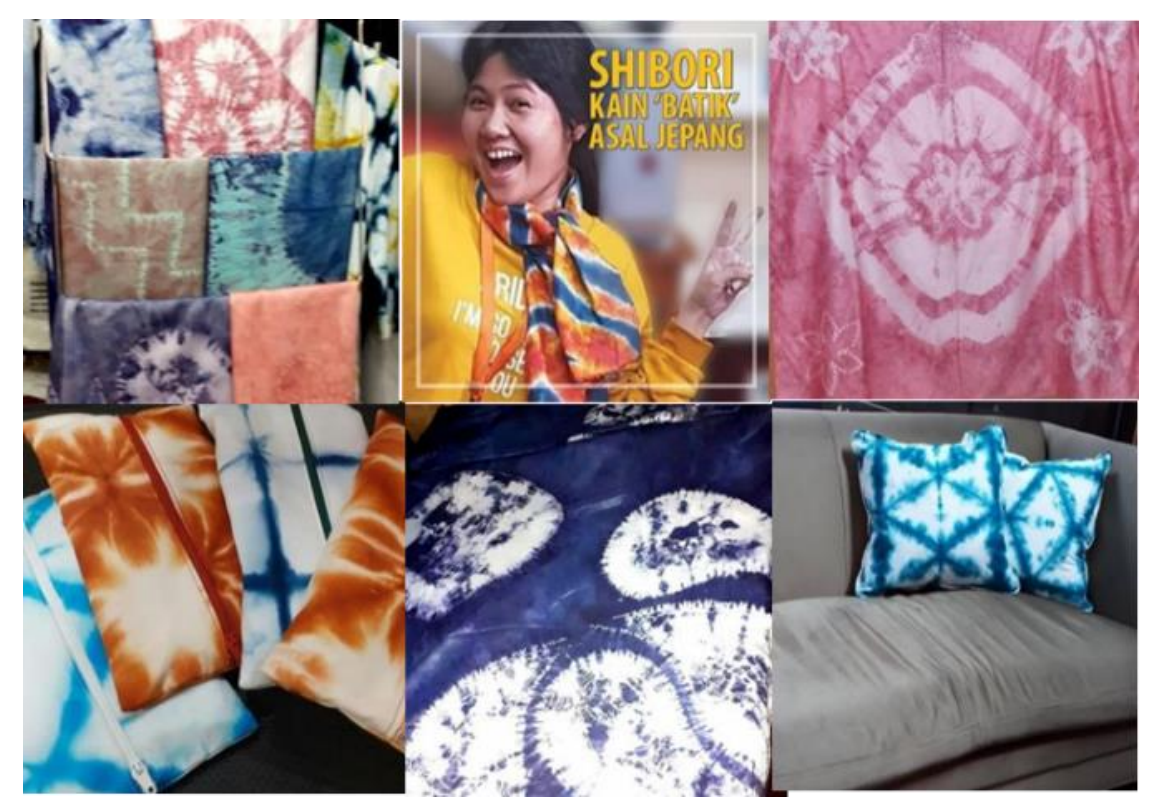

Gambar 2. Hasil pelatihan Teknik Celup Kain

Bahan baku yang digunakan tidak mahal, sehingga dapat meringankan orang tua ketika akan mencoba memproduksi untuk dijual. Hasil celup yang tidak akan memiliki motif yang sama menjadikan setiap produk dapat dijual kepasaran. Orang tua dijelaskan bahwa dengan tingkat kegagalan yang rendah maka harga jual dapat lebih menguntungkan. Yang perlu dikembangkan adalah kemampuan mengolah bahan yang telah dicelup menjadi produk dengan nilai jual dan mengikuti pasar. Kemampuan pemasaran tentunya tidak dapat dilakukan oleh para remaja autis, artinya orang tua harus bersedia membantu atau mendampingi.

Peserta diajarkan untuk memahami bahwa produk yang dihasilkan akan dijual ke pasaran sehingga harus dapat mengikuti standar yang telah ditentukan yaitu tepat waktu dan rapih. Pemahaman tersebut tentunya tidak dapat terbentuk dengan cepat. Proses penerimaan honor adalah salah satu yang membantu peserta memahami konsep berkarya dan berusaha. Hal serupa juga mulai dipahami oleh para orang tua yang mendampingi. Balai latihan juga menerapakan sistem pegawai terbaik sebagai pembelajaran motivasi diri. Terlihat secara perlahan pemahaman akan konsep berusaha mulai terbentuk pada peserta.

Penggunaan cara pelatihan secara daring menimbulkan sesuatu yang berbeda. Peran aktif orang tua sangat nampak. Pelatihan daring yang diikuti oleh 11 peserta tidak seluruhnya didampingi oleh orang tua. Dari hasil pendataan maka terdapat $70 \%$ dari 
peserta yang pendampingannya dilakukan langsung oleh orang tua. Pada proses yang berjalan $50 \%$ dari orang tua aktif untuk ikut serta mempelajari seluruh tahapan-tahapan yang dijarkan dalam teknik celup kain. Perhatian awal orang tua tertuju pada teknis pengerjaan dan cukup banyak bertanya serta ikut mempraktekan pada setiap sesi.

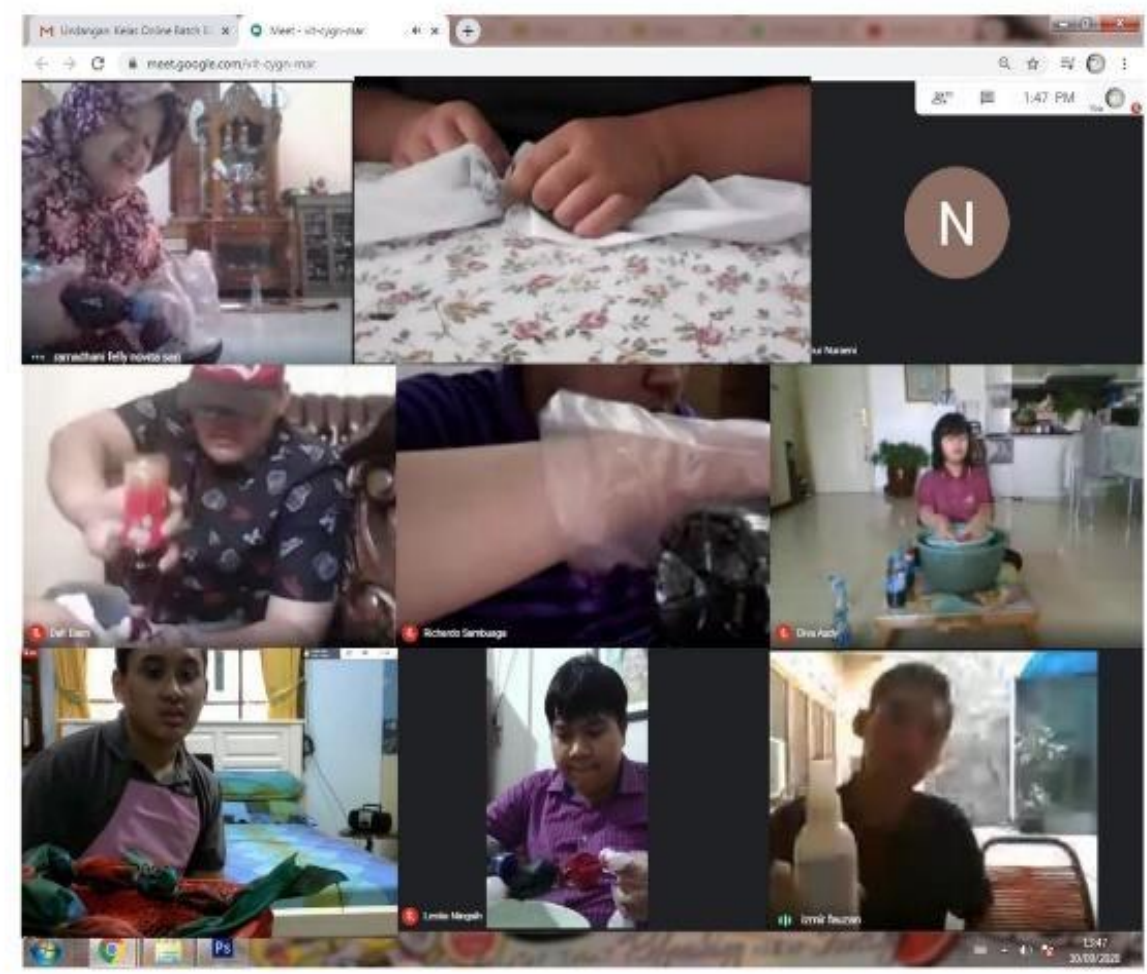

Gambar 3. Suasana Pelatihan Daring Teknik Celup Kain

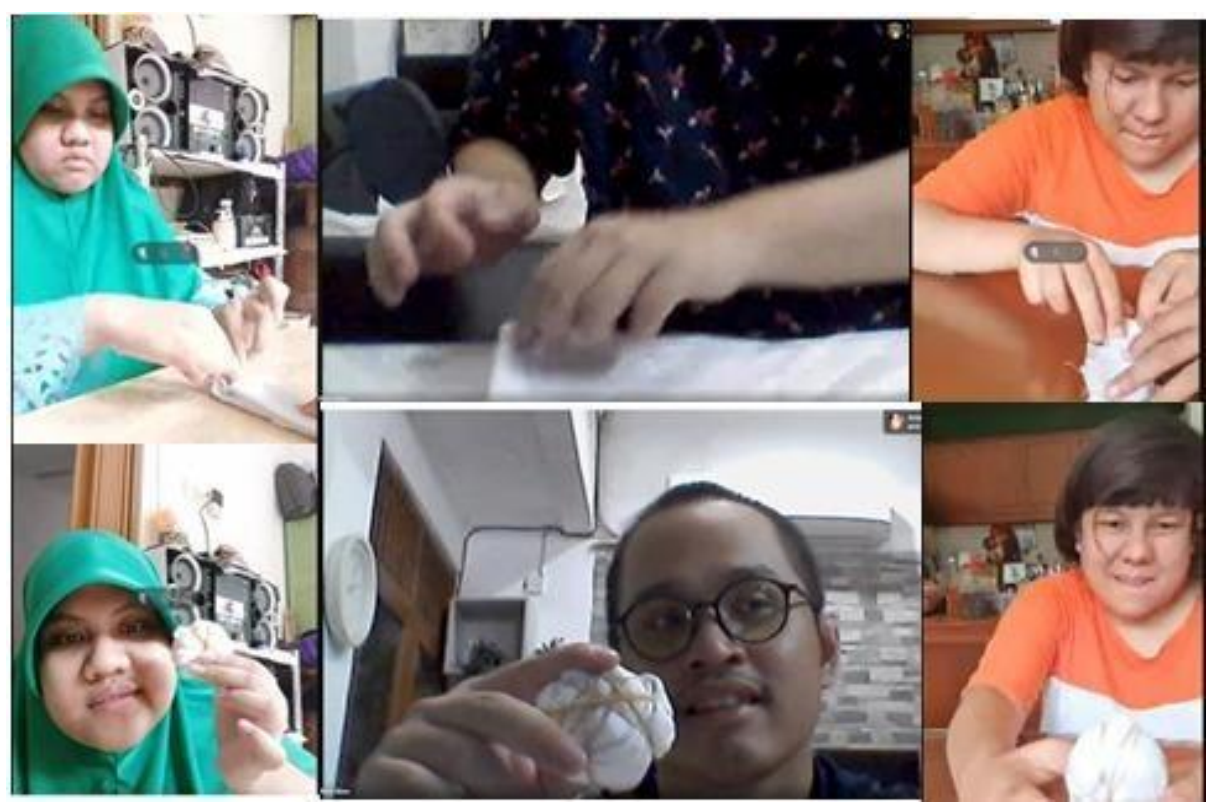

Gambar 4. Suasana Pelatihan Daring Teknik Celup Kain

Sarwahita : Jurnal Pengabdian Kepada Masyarakat Vol. 17 No. 2 Tahun 2020|136 


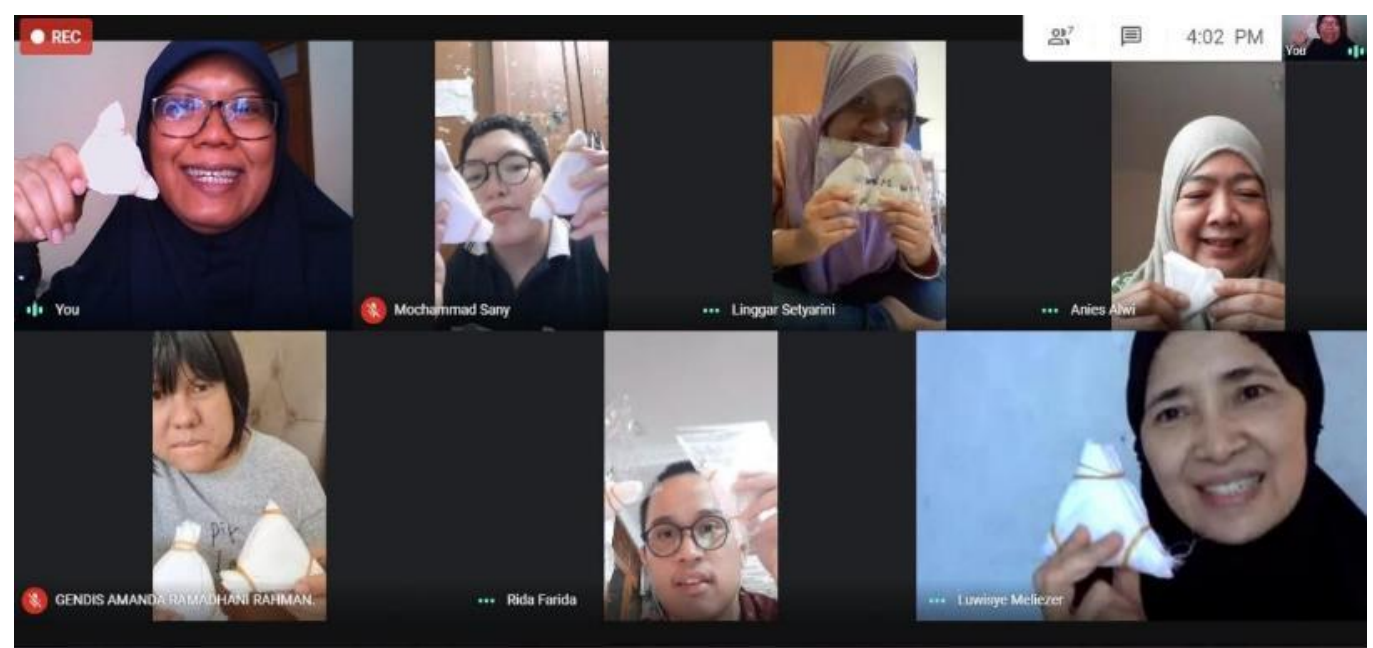

Gambar 5. Keaktifan pengajar ketika melakukan pembelajaran daring

Keaktifan orang tua merupakan sebuah temuan dalam program balai latihan. Hal tersebut tidak direncanakan semenjak awal secara khusus tetapi terjadi seiring berjalannya proses pelatihan. Hal-hal lain yang menjadi perhatian orang tua adalah modal yang harus dikeluarkan ketika akan memulai usaha, lokasi pembelian material, dan cara memasarkan. Merespon reaksi dari orang tua maka balai latihan mulai memberikan contoh-contoh pada setiap produksi yang dibuat, yaitu dengan mengkomunikasikan detail dari persiapan pra produksi. Pada proses berkreasi dengan kain yang telah dicelup, tim pengajar memberikan beragam referensi varian produk yang diminati di pasaran dan tidak terlalu sulit untuk dikerjakan.

Pembelajaran mengenai pemasaran produk diberikan dalam bentuk contoh yang telah dikerjakan oleh tim balai latihan, yaitu melalui media sosial. Orang tua diarahkan untuk mengemas kelebihan produk yang dihasilkan sehingga memiliki nilai lebih ketika dipasarkan. Seperti membuat video ketika produk dikerjakan, membuat testimoni dari pembeli, dan menampilkan cerita dibalik pembuatan produk tersebut. Media sosial berupa Instagram dan Facebook adalah paling banyak digunakan oleh orang tua. Berbekal hal tersebut maka orang tua tidak memerlukan usaha lebih dalam hal promosi. Melalui akun Instagram yang telah dimiliki balai latihan diberikan beragam referensi dimulai dari cara menampilkan produk, menuliskan caption, dan mencari tagar yang pas.

Hasil dari proses pelatihan balai latihan daring terlihat lebih efektif dibandingkan dngan tatap muka. Hal ini terlihat dengan munculnya dua usaha yang dikerjakan oleh remaja autis bersama orang tua. Pertama adalah produksi kaos dengan teknik celup yang dibuat oleh JC. Pengerjaan koas sepenuhnya dilakukan oleh JC setelah mengikuti pelatih, sedangkan persiapan dibantu oleh orang tua seperti pembelian material dan pengaturan waktu pengerjaan. Usaha ini baru dimulai pada 
bulan September 2020 setelah program balai latihan selesai diselenggarakan. Hingga saat ini penjualan dilakukan melalui rekomendasi dari mulut ke mulut
Penjualan hingga bulan November telah mencapai 200 buah kaos. Adapun hasil karya serta proses pembuatannya adalah sebagai berikut:

dan promosi melalui Instagram.

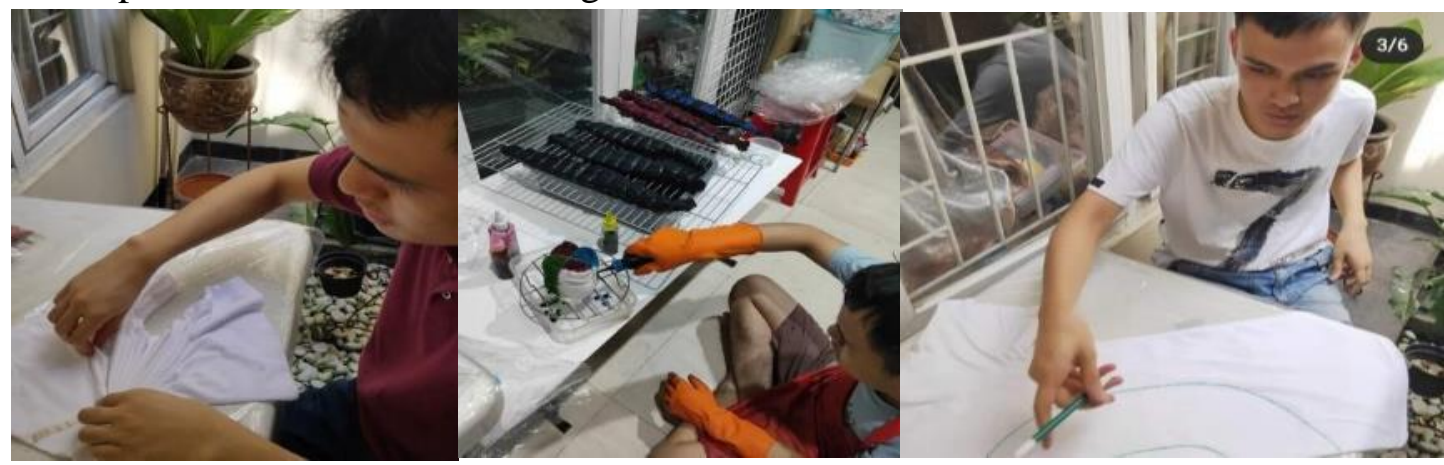

Gambar 6. Proses JC mengerjakan kaos

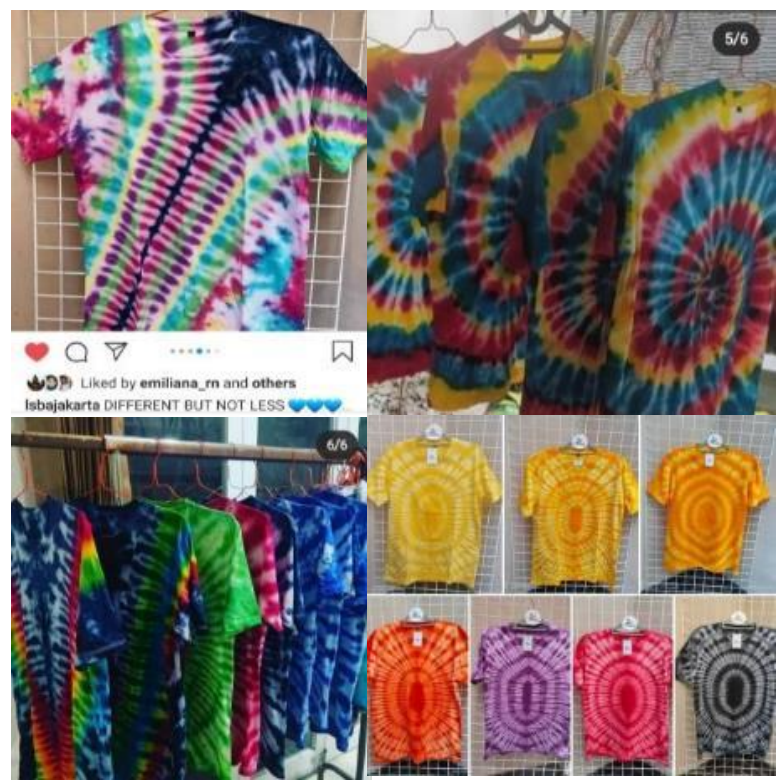

Gambar 7. Hasil Karya JC

Bentuk dari promosi yang dilakukan oleh JC dan orang tuanya melalui media sosial masih nampak sederhana. Pada penjualan awal akun yang digunakan masih bergabung dengan akun pribadi ibu dari JC. Setelah melakukan diskusi dengan pengajar balai latihan maka disarankan untuk memisahkan akun JC sehingga mudah dikenali sebagai media promosi. Sesuai dengan pelatihan maka produk dari JC diberi merek JC Creation yang memiliki arti sangat jelas bahwa seluruh produk adalah kreasi dari JC. Keterangan bahwa JC adalah remaja autis pada bio Instagram juga memperjelas kekhasan serta cerita dibalik produk yang dibuat. Adapun tampilan dari JC Creation adalah sebagai berikut: 


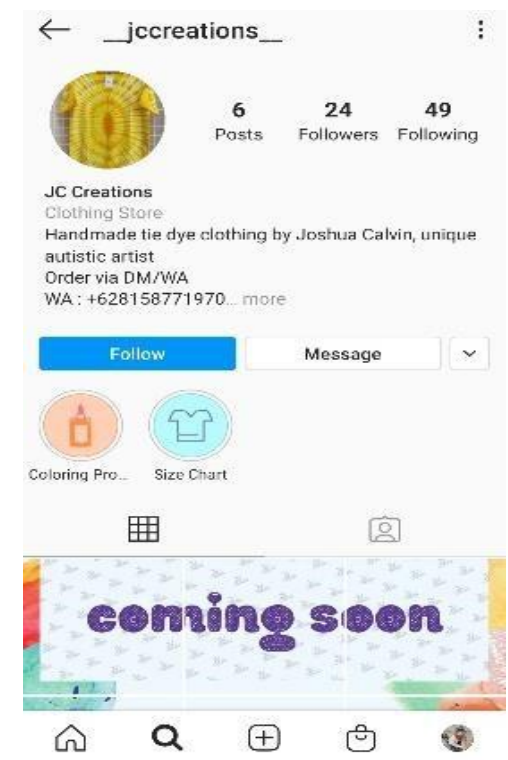

Gambar 8. Materi Promosi Melalui Media Sosial @_jcreation_

Wirausaha yang kedua adalah Y. Menampilkan teknik celup kain yang berbeda sehingga menghasilkan ragam motif yang lain dengan JC. Y didampingi orang tua memulai usaha pada bulan Oktober. Dengan teknik yang diajarkan Y didorong untuk berkreasi pada material lain selain kain katun atau kaos. Y menerapkan teknik celup pada kaos kaki, produk teknik celup yang masih jarang ditemukan. Keunikan produk yang dihasilkan menjadi nilai lebih dan dikemas dalam materi promosi melalui media sosial Instagram. Dituliskan bahwa penerapan teknik celup pada kaos kaki adalah sesuatu yang baru dan masih jarang dilakukan. Y juga mencoba menawarkan produk lain yaitu berupa kain siap olah dan kaos. Berikut adalah tampilan dari karya-karya Y.

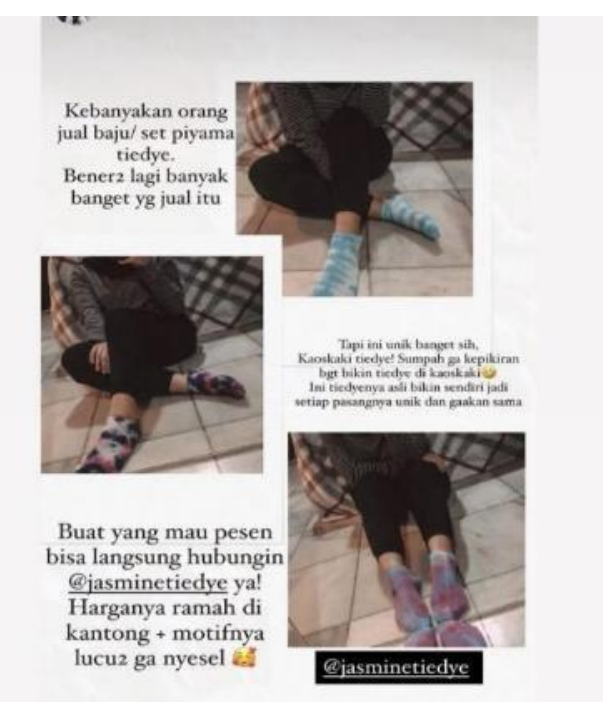

Gambar 9. Materi Promosi yang Menceritakan Keunikan Produk Y 
Pendampingan yang dilakukan oleh orang tua $\mathrm{Y}$ memberikan kemudahan untuk dapat menerapkan keterampilan dalam membuat kerajinan dengan ragam yang berbeda. Perilaku aktif dari orang tua Y sudah dimulai dari pertemuan pertama dengan mengamati seluruh tahapan-tahapan pencelupan dan menjalin komunikasi yang baik dengan pengajar. Pembelajaran melalui daring nampak membuat orang tua Y menjadi lebih leluasa mendampingi serta mengikuti.

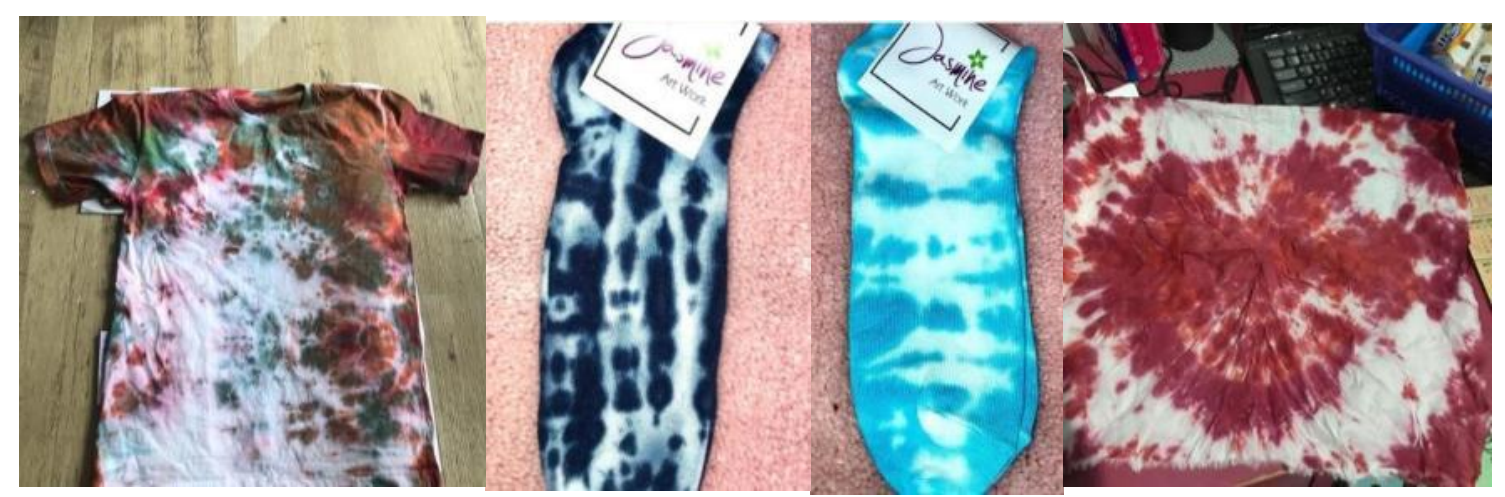

Gambar 10. Karya Teknik Celup Y pada Media Sosial @jasminetiedye

Hasil dan pembahasan berisi hasilhasil temuan pengabdian Masyarakat dan pembahasannya. Tuliskan temuantemuan yang diperoleh dari hasil-hasil penelitian yang telah dilakukan dan harus ditunjang oleh data-data yang memadai. Hasil-hasil pengabdian Masyarakat dan temuan harus bisa menjawab pertanyaan atau hipotesis pengabdian Masyarakat di bagian pendahuluan.

\section{PENUTUP}

Mengacu pada permasalahan yang diungkapkan sebelumnya bahwa bekal akademis belum menjawab kebutuhan akan kemampuan mandiri secara finansial bagi remaja autis dapat terjawab dari program balai latihan Beyond Creativity. Penggunaan teknologi daring dalam proses pembalajaran dapat membentuk keterampilan teknik celup kain. Hal tersebut terbukti dari beragam hasil pembelajaran yang memiliki nilai jual. Selain itu melalui daring mengkondisikan orang tua untuk mendampingi putra-putrinya ketika proses pembelajaran selama 6 bulan. Pendampingan tersebut tentunya secara tidak langsung memberikan wawasan baru baik dalam hal teknik pengerjaan karya hingga mencari ide pengembangan produk.

Ekonomi kreatif yang di dalamnya terdapat kerajinan menjadi salah satu jalan keluar bagi para remaja autis, tetapi komitmen dari orang tua dalam melakukan pendampingan. 2 dari 11 peserta balai latihan Beyond Creativity telah mampu memperlihatkan sebuah wirausaha yang dibentuk berdasarkan keterampilan dari remaja autis. Bermodalkan hal tersebut orang tua 
kemudian mengemas menjadi lebih menarik khususnya dalam ragam produk dan pemasaran. Pemasaran yang menjadi fokus orang tua ada pada media sosial dan promosi dari mulut ke mulut. Media sosial yang tidak asing tentunya memudahkan orang tua untuk mengoperasikannya. Pemahaman bahwa cerita dibalik produk menjadi penting disampaikan dari mulut ke mulut walaupun msaih dalam jangkauan yang terbatas.

Para remaja austis menjadi paham pada konsep berjualan setelah mengikuti pelatihan ini walaupun tidak secara menyeluruh. Pemahaman akan kegiatan bekerja untuk mendapatkan honor dapat dipahami dengan baik, tetapi ketika berkembang menjadi sebuah usaha masih agak sulit untuk dimengerti oleh mereka. Kemampuan untuk berkomitmen mengerjakan pesanan sesuai target juga dapat tercapai dengan kesadaran bahwa produk yang dihasilkan akan 'diberikan' kepada pihak lain. Pemahaman akan semua itu menjadi sebuah modal yang penting dalam membentuk usaha kerajinan bagai remaja autis dan keluarganya sebagai lingkaran tersedat dalam mendukung kemampuan berwirausaha.

Berdasarkan program tersebut maka masih ada beberapa hal yang dapat dikembangkan sehingga tujuan untuk membentuk wirausaha dalam ekonomi kreatif bagi remaja berkebutuhan khusus dapat terwujud. Program pelatihan harus ditambahkan pembelajaran mengenai dasar-dasar berwirausaha bagi para orang tua yang berjalan secara bersandingan, sehingga ketika program tersebut selesai maka sudah terbentuk motivasi untuk dapat menciptakan lapangan pekerjaan sendiri. Selain itu perlu program pendampingan selama beberpa bulan setelah pelatihan berlangsung dengna tujuan untuk dapat membantu memecahkan masalah ketika sebuah usah sudah mulai dijalankan. Adapun pelatihan yang diperlukan seperti perhitungan modal kerja, pembukuan sederhan, promosi daring, memahami merek, dan kreativitas dalam mengembangkan produk.

\section{DAFTAR PUSTAKA}

[BPS] Badan Pusat Statistik. 2019. Keadaan Ketenagakerjaan Indonesia Februari 2019.

Desideria B. 2017. Harapan Ibu Seorang Anak kepada Pemerintah Indonesia. [diunduh 2020 Des4]. Tersedia pada: https://www.liputan6.com/health/read/3 025328/harapan-ibu-seoranganak-autiskepada-pemerintahindonesia.

Febriyanti RH, Sundari H. 2020. Penerapan Penggunaan Platform Dalam Pengajaran Bahasa Inggris Berbasis Daring. Rangkiang. 2(1): 17-27.

Gumilar G. 2015. Pemanfaatan Instagram Sebagai Sarana Promosi Oleh Pengelola Industri Kreatif Fashion Di Kota Bandung. Jurnal Ilmu Politik dan Komunikasi. $\mathrm{V}(2): 77-84$.

Haryanto. 2010. Pendidikan Keterampilan Kerja Bagi Warga Berkebutuhan Khusus Melalui 
Pelayanan Keliling di Pedesaan.

Jurnal Pendidikan dan

Kebudayaan. 16(1). 104-115.

Kementerian Pendidikan dan

Kebudayaan. 2020. Jumlah Data

Satuan Pendidikan (Sekolah)

Khusus Per Provinsi.

Lestari NW. 2020. Strategi

Pengembangan Teknologi Dalam

Menumbuhkan Ekonomi Kreatif

di Indonesia. Indikator. 1(1): 5561.

Prahardika AA, Pradika AY. 2015. Made

By Disabled: Program

Pengembangan Potensi Difabel

Berbasis Ekonomi Kreatif dan

Ramah Lingkungan di Panti

Asuhan Bina Remaja Yogyakarta.

Proceeding of The First Youth

Conference on Sustainable

Development (IYCSD)

Purnomo RA. 2016. Ekonomi Kreatif:

Pilar Pembangunan Indonesia.

Surakarta: Ziyad Visi Media

Purwanta E, Hermanto, Sukinah,

Harahap F. 2016. Analisa
Kebutuhan Untuk Berwirausaha Pada Siswa Berkebutuhan Khusus. Cakrawala Pendidikan. XXXV(3). 339-348.

Rogers, EM. 1983. Diffusion of Innovations. New York (NY): The Free.

Sandi ED. 2020. PMPK Kemendikbud: Masih Ada Kesenjangan Pendidikan ABK dan

Dunia Kerja. [diunduh 2020 Des4].

Tersedia pada:

https://www.kompas.com/edu/read/2020 /09/14/152839571/pmpkkemendikbudmasih-adakesenjangan-pendidikan-abk-dandunia-kerja?page $=$ all.

Zamzani, Hastuti D. 2018. Determinan Penerimaan Daerah dan Pertumbuhan Ekonomi Terhadap Pengembangan Ekonomi Kreatif di Provinsi Jambi. Jurnal Paradigma Ekonomika. 13(1): 3745. 